\title{
Recent Advances in the Reutilization of Granite Waste in Various Fields
}

\author{
Di Wang, Jinshan Lu*, Junxiong Zhan, Zhiyong Liu and Bin Xie
}

School of Materials Science and Engineering, Nanchang Hangkong University, Nanchang 330063, China

\begin{abstract}
Quarrying and processing of granite produce large amounts of waste residues. Besides being a loss of resources, improper disposal of these wastes results in pollution of the soil, water and air around the dumpsites. The main components of granite waste are quartz, feldspars and a small amount of biotite. Due to its hard and dense texture, high strength, corrosion resistance and wear resistance, granite waste may be recycled into building materials, composite materials and fine ceramics, effectively improving their mechanical properties and durability. By using the flotation process, high value-added products such as potash feldspar and albite may be retrieved from granite waste. Also, granite waste has the potential for application in soil remediation and sewage treatment. This review presents recent advances in granite waste reutilization, and points out the problems associated with its use, and the related countermeasures, indicating the scale of high value-added reutilization of granite waste.
\end{abstract}

Keywords: Granite, Solid waste, Reutilization, Construction material, Fine ceramics.

\section{INTRODUCTION}

As a typical decorative architectural material, granite is an acidic volcanic rock formed by the condensation of magma in deep underground layers. Some granites have been metamorphosed into gneiss or migmatite. The main mineral is quartz, together with small amounts of anorthite, microcline, mica, hornblende and pyroxene, and secondary minerals (e.g., tourmaline, apatite, zircon, garnet and magnetite). Granite usually has a light color, but may become gray, pink or orange depending on the content of feldspar and other minerals [1]. Granite is widely distributed in large reserves around the world; the major producers of granite are China, Brazil, India, South Africa, Spain, Finland, Norway and the U.S.A. In the past decade, China's granite exports have increased steadily, and the disposal of granite processing waste has become a severe environmental challenge [2].

During the excavation of granite and subsequent mechanical processing, some cannot be used due to blasting damage, cracks and defects. Granite processing factories produce tens of millions of tonnes of waste residues, 40 percent of which is derived from the cutting and polishing processes [3]. The impact of granite waste on the environment is threefold: (1) marginally useful scrap generated during quarrying and processing, which is randomly discarded in farmlands and rivers, causing the pollutions of soils and water

*Address correspondence to this author at the School of Materials Science and Engineering, Nanchang Hangkong University, Nanchang 330063, China;

Tel: +86 791 6453203; E-mail: jinshan.lu@nchu.edu.cn resources; (2) dust generated from the cutting and polishing may be inhaled, causing lung damage [4]; and (3) cutting coolants (mineral oil, alkaline additives and surfactants) to reduce the wear on cutting saws and to reduce noise pollution are not readily precipitated and are strongly adhesive. Coolant discharge containing granite sludge pollutes farmland and rivers. Contamination of soils by granite waste permanently alters its texture, $\mathrm{pH}$, redox potential and conductivity, reducing moisture and organic matter content. In addition, the build-up of heavy metals from this source leads to the deterioration of soil quality [5].

At present, disposal of granite wastes is frequently treated in simple accumulation or landfill, and its reutilization is relatively low [6]. Figure 1 shows the extent of reutilization of granite waste in construction materials in various countries [7]. It is primarily used as aggregates, fillers or additives in construction materials. It does not adversely affect the product performance, but its economic value is low and utilization is limited accordingly. This review systematically introduces the status of granite waste reutilization and analyzes the problems and their countermeasures, thus, laying the foundation for sustainable development of the granite industry.

\section{STATUS OF GRANITE WASTE REUTILIZATION}

\subsection{Green Building Materials}

\subsubsection{Cements}

As indispensable cementitious materials, cements are extensively applied globally in modern housing and infrastructure. Cement production is one of the main 


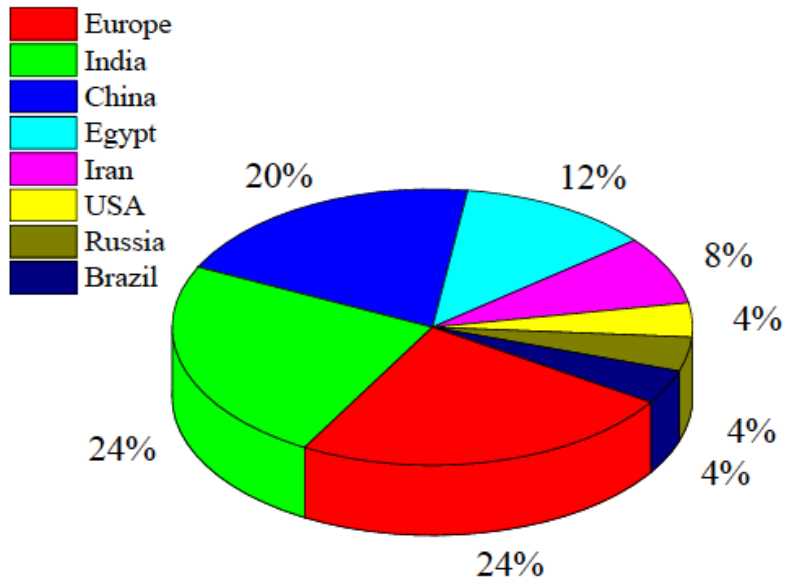

Figure 1: Reutilization of granite waste in construction materials in different countries.

sources of greenhouse gas. The production of 1 tonne of cement emits 1 tonne of $\mathrm{CO}_{2}$, and accounts for about 7 percent of total global emissions. Granite waste is frequently used to replace part of the raw materials in cement production, which helps to reduce $\mathrm{CO}_{2}$ emission [7]. Because the active silica in granite waste is very similar to the content in cement, it can be directly used in the production of ordinary Portland cement without any pretreatment [8]. The hydration reaction produces calcium silicate hydrate $(\mathrm{C}-\mathrm{S}-\mathrm{H}) \mathrm{gel}$ and layered double hydroxides (LDH). The content of $\mathrm{C}-\mathrm{S}-\mathrm{H}$ gel increases with time, which improves the durability of cement [9] and reduces the $\mathrm{CO}_{2}$ emission in the hydration reaction [10]. Granite powder plays an important role in forming a dense microstructure, improving the packing density of particles and reducing porosity, thus increasing the compressive strength of fly ash magnesium oxychloride cement [11].

When cement is used in oil well concreting material, granite waste is used to replace part of the silica fume, increasing the compressive and tensile strengths of the concrete by $5.7 \%$ and $39.3 \%$, respectively, and decreasing its permeability and porosity by $64.7 \%$ and $17.9 \%$, respectively [10]. The use of granite waste to partly replace the cement content has been found to improve the anti-corrosion performance of the concrete. Reports of controlled experiments indicate that it also has higher resistance to corrosion, frost and abrasion [12, 13]. Soaking in a sulfuric acid solution produces ettringite and precipitates gypsum in the pores, which increases the corrosion resistance of concrete components [14]. With a dense matrix in concrete, the expansion of concrete containing granite waste was reduced by $38 \%$. The aluminate in granite waste reacts with chlorides to form chloroaluminate, increasing chloride resistance by $70 \%$ [15].
Granite waste can be used to replace fine aggregate in the cement mortar. Compared with the traditional cement mortar, the difference in mechanical properties is very small, and conforms to European standards [16]. When $30 \%$ and $40 \%$ granite waste replace fine aggregate, the water content of cement mortar is reduced by $7 \%$ and $3 \%$, respectively. The lower water content helps to improve the mechanical properties of the mortar, and both the tensile strength and bonding strength are increased by $23 \%$ [17]. Marmol et al. [18] studied the role of granite waste in cement mortar and found that the addition of granite waste increases its compressive strength. The $\mathrm{Fe}_{2} \mathrm{O}_{3}$ in granite waste calcined at $700-900^{\circ} \mathrm{C}$ is converted to a reddish color. In this way, colored cement mortar can be prepared without affecting the compressive strength.

Refined granite waste improves the densification of the concrete and reduces its porosity. For a setting time of 7 to 28 days, the porosity and water absorption of all the tested cement mortars decreased with increasing setting time, and the bulk density increased with increased setting time [19]. The hydration product fills the pores in the mortar, thereby improving the compressive strength of the concrete after setting. The filling effect of granite waste produces a lower porosity matrix, which inhibits acid intrusion and improves its corrosion resistance. However, it was found that excessive substitution by granite waste in the mortar matrix leads to lower density and increased porosity, and reduces the compressive strength and corrosion resistance [20].

Using granite waste to simultaneously replace part of both sand and cement in mortar improves its strength and fluidity. After setting, it has a better overall 
performance, with a compressive strength up to 66.2 MPa [21]. In another study, nanosized granite powder was used to replace $5 \%$ of the cement and $10 \%$ of the sand in the mortar. The simultaneous replacement increased the hydration rate of the cement mortar, reduced its porosity and increased its 28-day compressive strength [22].

\subsubsection{Concrete and Geopolymers}

Concrete is the most important building material in civil construction works and other infrastructure. The fine aggregate in concretes accounts for about $35 \%$ of its volume. River sand is a commonly used natural fine aggregate, but is faced with increasingly depleted resources and strict restrictions in environmental protection regulations. The main minerals in granite waste are quartz and feldspars, which have characteristics of granulation, compactness and water absorption similar to river sand. The addition of granite waste into concrete has been found not to affect the concrete structure or the formation of hydration products [23]. Taji et al. [24] studied the mechanical properties of concretes containing granite waste and its effect on the corrosion of steel reinforcing bars. The addition of $10 \%$ granite waste distinctly improved corrosion resistance. When $20 \%$ of granite waste was added, the mechanical properties of concrete were not affected, indicating that granite waste is a high-quality aggregate in the concretes.

\section{(1) Compressive Strength}

Compared with natural fine aggregate, coarse granite powder (CGP) has a rougher surface, and the angle and geometry of the particles vary greatly. The specific particle surface produces higher friction in cement slurry, implying that it is suitable as a concrete aggregate. Figure $\mathbf{2}$ compares the compressive strength of concretes with added granite powder for different setting times. Compared with the control sample (CM), the addition of granite powder basically did not affect the compressive strength of concretes, which in fact increased with longer setting times. The optimal replacement amount was found to be $10 \%$ [25].

Due to the large surface area of fine granite particles, an excessive addition of granite powder increases the amount of cement binder, resulting in poor density and reduced compressive strength [26]. After the addition of granite powder, the C-S-H phase in the concrete increases, while the calcium hydroxide $(\mathrm{CH})$ phase decreases. The increased density and reduced porosity of the concrete are favorable for increasing the compressive strength and reducing water absorption [27].

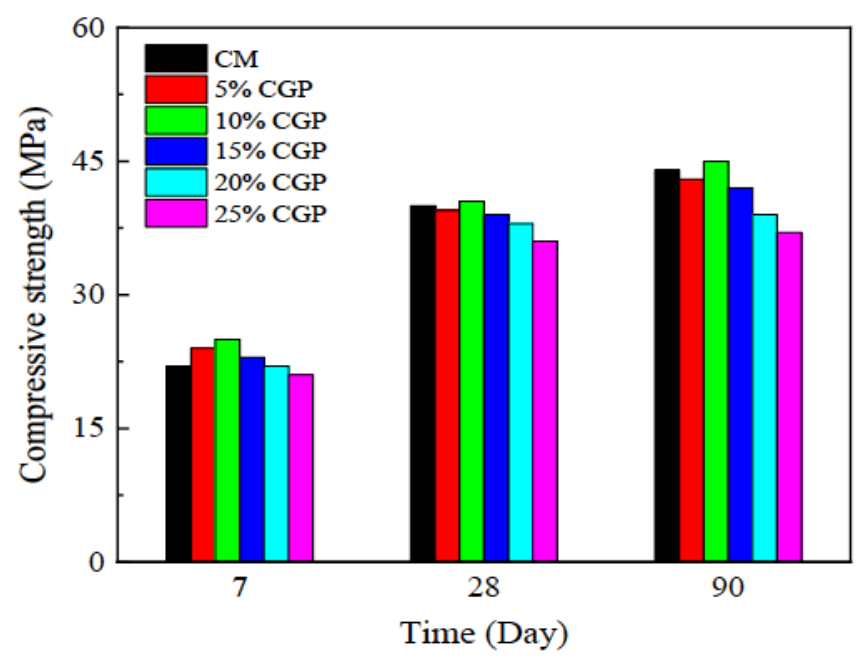

Figure 2: Variation of compressive strength of granite-added concretes vs. setting time.

When marble and granite powders are used as the concrete mineral admixture, the fine particles fill the pores and effectively disperse the cement, producing concrete with stronger cohesion and denser microstructure, which improves its compressive strength [28]. The granite sludge generated by the gang saws contains worn steel particles. The dense mixture of steel particles and granite particles contains $15 \% \mathrm{Fe}_{2} \mathrm{O}_{3}$ and up to $5 \% \mathrm{CaO}$, which can be used to prepare ultra-high-performance concrete [29]. It has been found [30] that the addition of steel fibers to selfcompacting concrete with granite significantly improves its compressive strength, exceeding $55 \mathrm{MPa}$ with $0.2 \%$ added steel fibers. Likewise, increased compressive strength of concrete with granite powder was achieved by partially replacing cement and fine aggregate with $10 \%$ wollastonite fibers [31].

\section{(2) Flexural Strength}

Granite waste has been used to replace fine sand in the production of self-compacting concrete [32], increasing the flexural strength by $5.65 \%$ after 28 days setting time. This is due to the rough surface of the granite particles, which causes rigid accumulation between cement and aggregate. The granite particles provide a hard filling in the concrete, thereby improving the flexural strength. For a water: cement ratio of 0.30 0.40 , the 28-day flexural strength of the mixture with $25 \%$ granite waste was the largest. The increase in flexural strength is due to the enhanced adhesion between the aggregate and the cement paste [33]. Due to high content of $\mathrm{C}-\mathrm{S}-\mathrm{H}$ in the hydration products, the 
flexural strength of the modified concrete was 20-50 $\mathrm{MPa}$, which is $15 \%-60 \%$ higher than that of ordinary concrete [27].

Patil et al. [34] used granite waste and copper slag to replace $30 \%$ of the river sand in concrete. After 28 days the flexural strength of the concrete increased by $5 \%$, but as the replacement increased, too much water remained in the concrete and increased the porosity, and both the compressive strength and flexural strength were reduced. When the fine aggregate was composed of river sand and granite waste, the early flexural strength of the concrete was relatively low, but it increased by $3.6,9.5$ and $13.4 \%$ with the setting times of 28 days, 56 days and 90 days, respectively [35].

\section{(3) Durability}

Concretes using granite waste as fine aggregate were subjected to chloride ion penetration experiments [25]. Higher aggregate replacement resulted in greater chloride permeability. This was attributed to poor compaction, resulting in a high-porosity microstructure and discontinuous pore system. Nevertheless, the permeability of concrete containing less than $15 \%$ of granite waste was substantially the same as for the control group. After setting for 180 days and 365 days, the concretes were soaked in $\mathrm{Na}_{2} \mathrm{SO}_{4}$ and $\mathrm{MgSO}_{4}$ solutions for the acid resistance experiments. The compressive strength of the concrete with granite waste was largely lost; this became more serious with increase of replacement ratio. The use of petroleum ether (hydrocarbon) to chemically bleach the granite waste to remove the organic matter improved the sulfate resistance of concrete.

Granite waste was substituted for river sand to prepare autoclaved aerated concrete. An acid erosion experiment was carried out in $5 \% \mathrm{HCl}$ and $5 \% \mathrm{H}_{2} \mathrm{SO}_{4}$ solutions. The compressive strength loss in $\mathrm{HCl}$ solution was $19.44 \%$ and $13.14 \%$ for the control and $20 \%$ for the replacement samples. The compressive strength losses in $\mathrm{H}_{2} \mathrm{SO}_{4}$ solution were $27.88 \%$ and $12.82 \%$, respectively, indicating that granite waste aggregate effectively improves the acid resistance of concretes $[36,37]$. The water absorption of concretes was tested using magnetized water with higher water molecular activity, and it was found that concrete with granite waste had a reduced water absorption and significantly improved compressive strength and acid erosion resistance [38]. The addition of soda lime glass powder increases the concrete density, reduces its water permeability and water absorption, and further improves its acid resistance [39].

As a cementitious material, geopolymers have excellent mechanical strength, heat resistance and favorable stability in acidic and alkaline environments. The main component of granite waste is siliconaluminum oxide, suitable for the production of geopolymers by the alkali activation method. Granite waste reacts with the alkaline activator (sodium silicate, or water glass) to form a geopolymer binder mainly composed of sodium aluminosilicate hydrate $(\mathrm{N}-\mathrm{A}-\mathrm{S}-\mathrm{H})$ gel. Depending on the amount of $\mathrm{Na}_{2} \mathrm{O}$ and curing time in the alkali activation process, the compressive strength of geopolymer mortar reaches up to $40.5 \mathrm{MPa}$ [40]. When the activator solution consists of $18 \%$ $\mathrm{Na}_{2} \mathrm{SiO}_{3}, 7 \% \mathrm{NaOH}$ and $75 \%$ distilled water, the silicon-based geopolymer from granite waste has a maximum compressive strength of $22 \mathrm{MPa}$ after curing at $220^{\circ} \mathrm{C}$ for $2 \mathrm{~h} \mathrm{[41].}$

Extending the curing time improves the flexural strength and crack resistance of granite waste geopolymer. The content of granite waste and water glass has the greatest impact on the flexural strength; the alkali content has little effect on the flexural strength of the geopolymer mortar [42]. When metakaolin and blast furnace slag were used as the starting materials for geopolymer synthesis, the bonding strength between the geopolymer and the granite aggregate decreased with increase in the activator modulus and the liquid/solid ratio, but it was much higher than between cement paste and granite. A liquid/solid ratio of 0.35 gives a maximum bonding strength of $1.53 \mathrm{MPa}$ [43].

When nanosized alumina (Al-0450) and liquid hydroxyl functionalized nanotubes (MWCNT-OH) were added to granite waste-based geopolymers (GP), they were uniformly distributed within the geopolymers to form a dense and ductile structure, resulting in enhanced mechanical properties and delayed setting times for the slurries, as shown in Figure 3 [44].

\subsubsection{Unfired and Fired Bricks}

Granite powder has been used as part of the fine aggregate in the preparation of hollow concrete blocks. With a liquid/cement ratio of 0.55 and a fine/coarse aggregate ratio of $15 \%$, the prepared blocks meet the strength requirements and have good frost resistance [45]. For sintered floor tiles and clay bricks, the addition of granite waste increases the bulk density and mechanical properties [46-48]. This is attributable to 

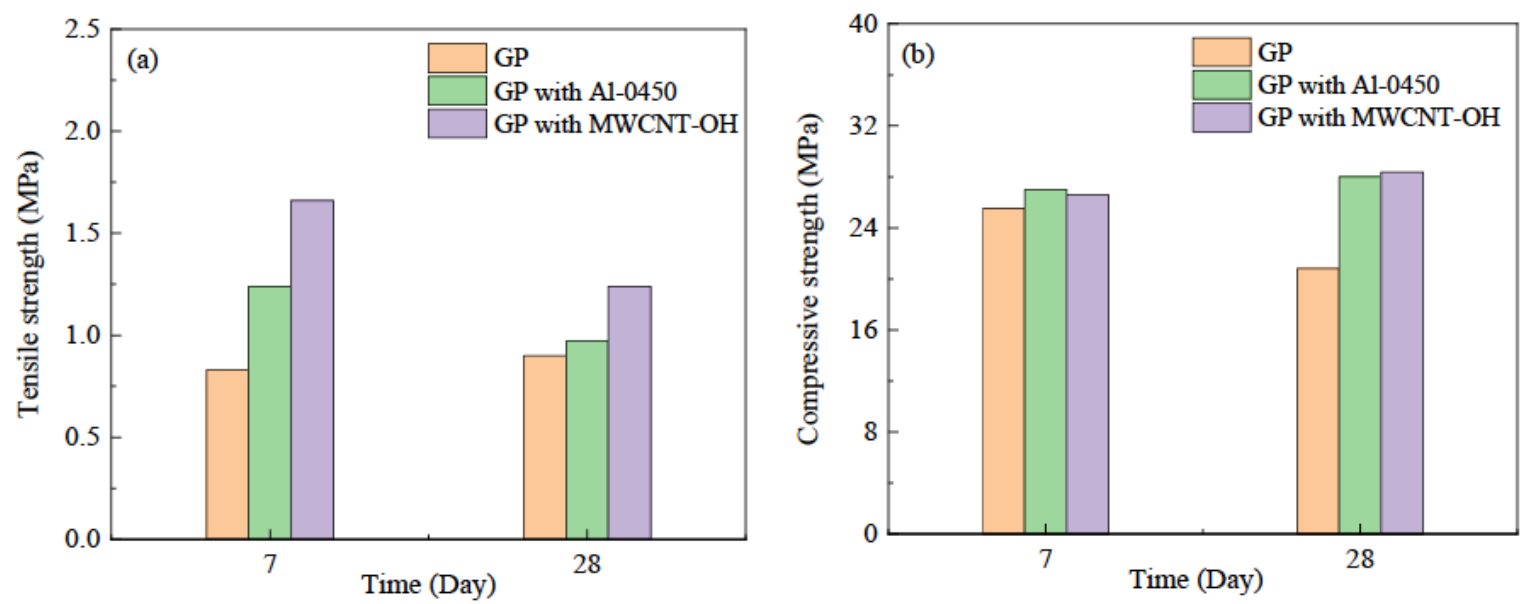

Figure 3: Mechanical strength of granite-based geopolymers with different setting times. (a) tensile strength, (b) compressive strength.

the densification by liquid-phase sintering and is derived from the low-temperature melting of alkali feldspars in the granite waste.

\subsection{Composite Materials}

Composite materials are filled with granite powder to improve their mechanical properties and durability. For example, in wind turbine blade manufacture, composite materials with a density of 1.108 to 1.321 $\mathrm{g} \cdot \mathrm{cm}^{-3}$ were prepared by adjusting the addition of granite powder without changing the contents of polyamide fibers and polyester resin. In air jet erosion experiments, the addition of less than $10 \%$ granite dust had a minor effect on the erosion rate of composites. Conversely, the Rockwell hardness increased with increased granite powder content: a composite with $5 \%$ granite dust withstands up to $60^{\circ} \mathrm{C}$ [49]. In the case of decorative construction materials, marble and granite powder were added to high-density polyethylene to prepare a new type of composite material [50]. The flexural strength of the composite increased up to 23.5 $\mathrm{MPa}$ with increasing marble and granite powder content. Similarly, a composite material prepared with epoxy resin as the matrix and granite powder as the reinforcement [51] gave a Vickers hardness and impact strength of 22.93 and $42 \mathrm{~J} \cdot \mathrm{m}^{-2}$, respectively. These composites are typical of simple, low-cost manufacturing processes.

Environmentally friendly composites have successfully been prepared using acrylonitrile butadiene styrene (ABS) and granite powder as raw materials [52]. The stiffness and thermal conductivity of the composites increased and the elastic modulus more than doubled with increasing content of granite powder; the flexural strength and fracture toughness decreased with the addition of more than $50 \mathrm{wt} \%$ granite powder.

To investigate the deterioration of mechanical properties, granite powder was modified by stearic acid to disperse granite particles in polystyrene composites [53]. Although the bending and impact strength of composites decreased with increased granite powder content, their surface hardness was increased by $130 \%$.

Incorporation of granite powder into natural-fiberreinforced polyester composites [54] continuously increased the tensile, flexural and impact strengths of the composites with increase of granite filler content up to $15 \%$, then deteriorated due to the agglomeration of granite particles.

Polypropylene has excellent properties such as dimensional stability, thermal stability, optical properties, flame retardancy and high deformation temperature. The addition of granite powder to polypropylene was found to reduce the thermal expansion coefficient and improve heat resistance of the composite material [55].

\subsection{Sintered Ceramics and Glass-Ceramics}

Sintering in ceramic manufacture usually needs the addition of sintering additives. The liquid phase formed at the sintering temperature, viscosity and surface tension are important factors for selecting sintering additives. The chemical composition of granite waste contains alkaline oxides and alkaline earth oxides, which are suitable as sintering additives [56]. In the 
production of red ceramics, the alkaline oxides in granite waste reacts with silica and alumina to form a liquid phase, which promotes the densification of the ceramic and reduces its porosity [57]. Naga et al. [58] reported using granodiorite as a sintering additive. The sintered ceramics consist of primary and secondary mullites, glass phase and pores. With the addition of $35 \%$ granodiorite, the flexural strength was $41.1 \mathrm{MPa}$. In addition, periclase-forsterite ceramics have been sintered from magnesia and granite sludge by a temperature-induced forming method [59]. When the granite sludge increased from 10 to $40 \mathrm{wt} \%$, the forsterite phase increased by up to $78 \%$, and the microhardness increased to $7.9 \mathrm{GPa}$. The forsterite was formed by the diffusion of the granite sludge into the periclase phase.

Granite powder has been directly used to prepare sintered glass-ceramics. The effects of sintering additives on the densification, crystallization and flexural strength of glass-ceramics have been thoroughly investigated [60]. Boehmite is more suitable than silica sol and glass powder for the densification of glass-ceramics. At a sintering temperature of $1075^{\circ} \mathrm{C}$, the bulk density of glass-ceramic is $2.49 \mathrm{~g} \cdot \mathrm{cm}^{-3}$ and the flexural strength is as high as $125 \mathrm{MPa}$. With increasing rate of sintering heating, the densification, crystallinity and mechanical properties were all completely improved [61]. Figure 4 shows the effect of sintering heating rate on flexural strength, Vickers hardness and fracture toughness of the sintered glassceramics. When sintered to $1085^{\circ} \mathrm{C}$ at a heating rate of $50^{\circ} \mathrm{C} \cdot \mathrm{min}^{-1}$, the main crystalline phase was anorthite with a flexural strength of $143 \mathrm{MPa}$ and fracture toughness of $2.1 \mathrm{MPa} \cdot \mathrm{M}^{1 / 2}$.

Pickling asbestos and mullite fiber have been used as the reinforcement in the sintering of anorthite glass- ceramics from granite powder [62]. With increasing fiber addition, the bulk density, flexural strength and fracture toughness of glass-ceramic first increased and then decreased, but the Vickers hardness continued to decrease. When $3 \%$ pickling asbestos is added, the flexural strength reached $144 \mathrm{MPa}$, with fracture toughness of $3.0 \mathrm{MPa} \cdot \mathrm{M}^{1 / 2}$. In addition, granite powder was physically pretreated by magnetic separation to remove the iron-containing impurities for the decorative aesthetics of sintered glass-ceramics.

The crystal composition of glazed glass-ceramics consists of anorthite, albite and quartz. The surface glossiness of glass-ceramics is 82 gloss units (GU), and the flexural strength is up to $108.4 \mathrm{MPa}$ [63]. As an architectural decorative material, copper-red glassceramics has successfully been prepared from granite waste with the incorporation of $\mathrm{CuO}$ [64]. The rod-like richterite endows excellent mechanical properties to glass-ceramics, with a flexural strength of $167.8 \mathrm{MPa}$ and Vickers hardness of $7.62 \mathrm{GPa}$.

\subsection{Recovery of Feldspar Minerals}

Feldspars are important raw materials for the ceramic and glass industries, and the non-renewable mineral resources are increasingly being consumed. Granite waste contains a considerable amount of $\mathrm{K}$ feldspar and Na-plagioclase, with an average content of $28.5 \%$ and $39.7 \%$, respectively, making it a potential source of feldspar minerals $[65,66]$. Beneficiation methods recover quartz, albite and potash feldspar from granite waste, and remove the colored impurities such as mica, iron oxides and ferro-titanium gangue. Using a combination of gravity separation and magnetic separation to reduce the content of colored impurities, the mechanical properties of sintered granite
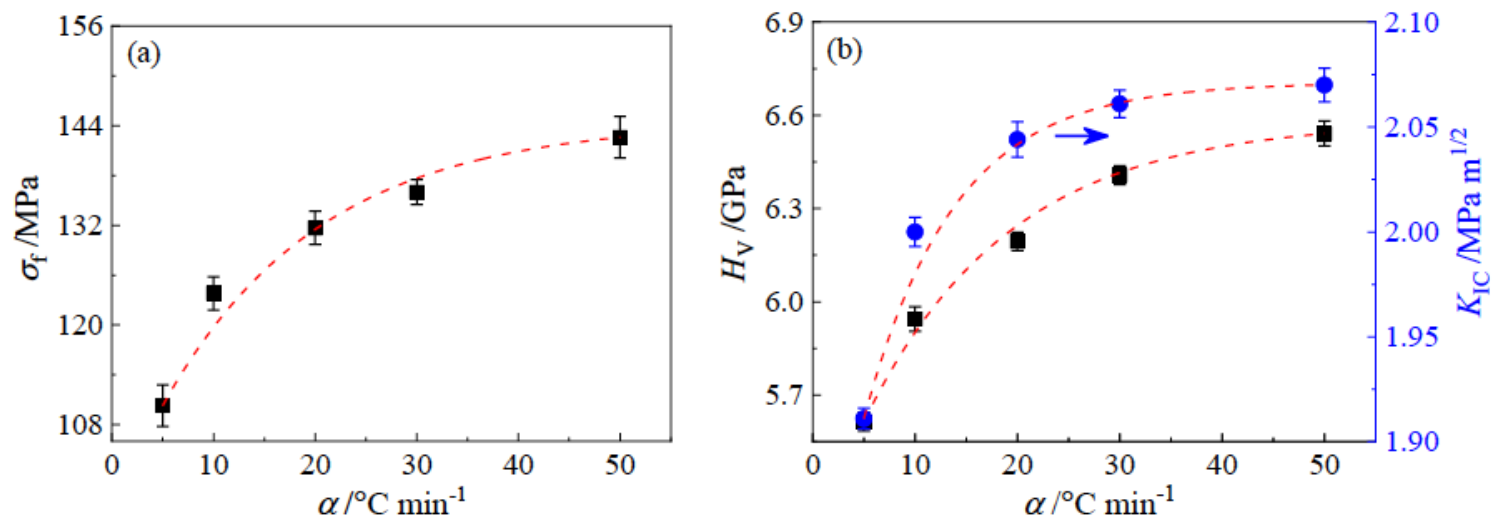

Figure 4: Effect of heating rate on the mechanical properties of sintered glass-ceramics. (a) flexural strength, (b) Vickers hardness and fracture toughness. 
products are considerably better than natural granite [67].

Magnetic separation reduces the iron oxide content in granites to $0.2 \%$. Froth flotation further removes mica and iron-titanium gangue, obtaining a feldspar/quartz concentrate with an iron content of $0.08 \%$ and with fewer impurities than magnetic separation. The concentrates obtained by both methods meet the requirements of the ceramics industry [68].

Cationic flotation technology has been used to separate $\mathrm{Na}$ - and K-feldspars from granite, with $\mathrm{NaCl}$ as the depressing agent to increase the K-feldspar grade in the concentrate [69], with recovery rates for orthoclase and albite at $70.18 \%$ and $28.27 \%$, respectively. Figure $\mathbf{5}$ is a schematic of feldspar extraction from granite waste. It is notable that some critical raw materials, especially Li-mica and $\mathrm{Nb}-\mathrm{Ta}-\mathrm{Ti}$ mineral phases, can be recycled from the hydrothermally altered granite using a combination of gravity, magnetic and heavy liquid separation [70].

\subsection{Environmental Protection}

Urbanization leads to extensive changes in the use of agricultural land in urban areas, and diazonium fertilizers for vegetable plants has accelerated soil acidification [71]. The acidic wastewater discharged from mining operations is another cause of soil acidification [72]. The $\mathrm{pH}$ of acidic sandy soil is usually less than 4.5 , while granite waste is alkaline $(\mathrm{pH}>9)$ and can be used as an effective acid soil amendment [73]. The acidic environment increases the solubility of granite, so that the alkaline cations ( $\mathrm{Ca}, \mathrm{Mg}, \mathrm{Na}$ and $\mathrm{K}$ ) on the surface of the silicates are quickly released. It can be used as a source of plant nutrients in acidic soils. For example, K-feldspar can be used as a high- efficiency fertilizer following hydrothermal alteration or high-temperature calcination $[74,75]$.

Black cotton soil is decomposed black lava, but due to its high content of montmorillonite and large soil expansion, it cannot be directly used as a construction material. The addition of granite waste increases the plastic index and maximum dry density of black cotton soil; also, the California bearing ratio is increased, making it suitable as a road subgrade material [76]. Granite waste has also been used as a stabilizer in expansive, highly plastic soils. With $70 \%$ added granite waste, the swelling index of such soils has been found to decrease from $58.3 \%$ to $11 \%$ after curing for seven days [77].

Granite waste is used in wastewater treatment to remove specific pollutants. Adding the fungus Aspergillus Niger to granite waste removes phosphate ions from wastewater, suggesting a cheap and ecofriendly material for phosphate removal [78].

Iron-rich granite waste in the presence of hydrogen peroxide catalytically degrades organic orange dye by the solar photo-Fenton process [79]. The dye solution is completely decolorized and effectively mineralized, achieving $68.7 \%$ total organic carbon removal at $\mathrm{pH}$ 3.0. This indicates that granite waste is an efficient heterogeneous photo-Fenton catalyst. A mixture of granite powder and pine bark compost has a high hexavalent chromium $(\mathrm{Cr}(\mathrm{VI}))$ adsorption capacity and is used in sewage treatment as a permeable reactive barrier in groundwater remediation [80].

The addition of $15 \%$ granite sludge has been found to be sufficient to stabilize heavy metals in hazardous industrial sludge. The aluminosilicates or silicate matrix within the granite sludge transforms heavy metals in their insoluble hydroxides or adsorbed in the stabilized matrix [81].

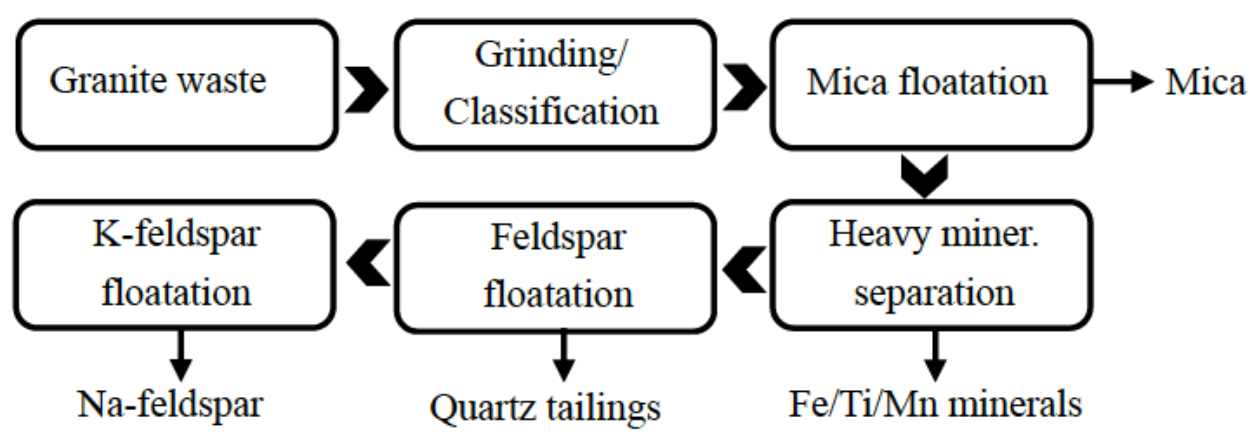

Figure 5: Flowchart of feldspar flotation from granite waste. 


\section{FUTURE OUTLOOK}

Numerous studies have been conducted on the reutilization of granite waste. Its reutilization in building materials could recycle granite waste in large quantities. From the viewpoint of economic value, granite wastes are distributed at different processing sites, and the transportation cost is not acceptable for industrial-scale utilization. Because local governments attach much importance to environmental protection and mineral sustainability, corresponding policies and financial support should be put forward to promote cooperation between research institutes and related enterprises in exploring novel technologies for the scalable and value-added utilization of granite waste. In building materials, architectural glass-ceramics is a high-grade decorative material that has been developed in the past two decades. After colored impurities are removed, granite waste can be used to produce architectural glass-ceramics in order to improve its added value. To explore the utilization routes, granite waste can be used as the substitute for feldspar minerals, marble processing abrasives $[82,83]$, and soda lime glass raw materials [84]; and so on. Such lines of research favor the scalable and value-added utilization of granite waste.

\section{ACKNOWLEDGEMENTS}

This work was financially supported by the National Natural Science Foundation of China (52060020).

\section{REFERENCES}

[1] Ballouard C, Poujol M, Boulvais $P$, et al. Magmatic and hydrothermal behavior of uranium in syntectonic leucogranites: The uranium mineralization associated with the Hercynian Guérande granite (Armorican Massif, France). Ore Geology Reviews 2017; 80: 309-331. https://doi.org/10.1016/j.oregeorev.2016.06.034

[2] Yan X. Overview of the world stone industry trend in 2018. Stone, 2019; (7): 39-41. (in Chinese)

[3] Quan JW. Study on mechanical behavior of concrete block from granite waste. Master dissertation, Zhengzhou University, Zhengzhou, 2013.

[4] Ahmad I, Khan MI, Patil G, et al. Evaluation of cytotoxic, genotoxic and inflammatory responses of micro- and nanoparticles of granite on human lung fibroblast cell IMR-90. Toxicology Letters 2012; 208(3): 300-307. https://doi.org/10.1016/j.toxlet.2011.11.004

[5] Reddy K, Yarrakula K. Geo-chemical exploration of granite mining waste using XRD, SEM/EDX and AAS analysis. Iranian Journal of Chemistry and Chemical Engineering (IJCCE) 2019; 38(2): 215-228.

[6] Chen C. Treatment situation of solid waste and its resource utilization in China. Environmental Sanitation Engineering 2016; 24(2): 31-33. (in Chinese)

[7] Arel HS, Shaikh FUA. Semi-green cementitious materials from waste granite by considering the environmental, economic, and health impacts: A review. Structural Concrete
2019; 20(1): 455-470.

https://doi.org/10.1002/suco.201700166

[8] Medina G, Bosque IF, Frías M, et al. Mineralogical study of granite waste in a pozzolan/ $\mathrm{Ca}(\mathrm{OH}) 2$ system: influence of the activation process. Applied Clay Science 2017; 135: 362371.

https://doi.org/10.1016/j.clay.2016.10.018

[9] Yagüe S, Gaya CG, Prieto VR, et al. Sustainable ecocements: chemical and morphological analysis of granite sawdust waste as pozzolan material. Materials 2020; 13(21): 4941.

https://doi.org/10.3390/ma13214941

[10] Chajec A. Towards the sustainable use of granite powder waste for manufacturing of cementitious composites. MATEC Web of Conferences 2020; 322: 01005. https://doi.org/10.1051/matecconf/202032201005

[11] Li Y, Yu HF, Zheng LN, et al. Compressive strength of fly ash magnesium oxychloride cement containing granite wastes. Construction and Building Materials 2013; 38: 1-7. https://doi.org/10.1016/j.conbuildmat.2012.06.016

[12] Ghorbani S, Taji I, Tavakkolizadeh M, et al. Improving corrosion resistance of steel rebars in concrete with marble and granite waste dust as partial cement replacement. Construction and Building Materials 2018; 185: 110-119. https://doi.org/10.1016/j.conbuildmat.2018.07.066

[13] Mashaly AO, Shalaby BN, Rashwan MA. Performance of mortar and concrete incorporating granite sludge as cement replacement. Construction and Building Materials 2018; 169: 800-818. https://doi.org/10.1016/j.conbuildmat.2018.03.046

[14] Medina G, Saez Del Bosque IF, Frias M, et al. Sulfate resistance in cements bearing ornamental granite industry sludge. Materials 2020; 13(18): 4081.

https://doi.org/10.3390/ma13184081

[15] Ramos T, Matos AM, Schmidt B, et al. Granitic quarry sludge waste in mortar: effect on strength and durability. Construction and Building Materials 2013; 47: 1001-1009. https://doi.org/10.1016/j.conbuildmat.2013.05.098

[16] Medina G, Sáez del Bosque IF, Frías M, et al. Granite quarry waste as a future eco-efficient supplementary cementitious material (SCM): scientific and technical considerations. Journal of Cleaner Production 2017; 148: 467-476. https://doi.org/10.1016/j.jclepro.2017.02.048

[17] Gupta LK, Vyas AK. Impact on mechanical properties of cement sand mortar containing waste granite powder. Construction and Building Materials 2018; 191: 155-164. https://doi.org/10.1016/j.conbuildmat.2018.09.203

[18] Mármol I, Ballester P, Cerro S, et al. Use of granite sludge wastes for the production of coloured cement-based mortars. Cement and Concrete Composites 2010; 32(8): 617-622. https://doi.org/10.1016/j.cemconcomp.2010.06.003

[19] Heikal M, El-Didamony H, Morsy MS. Limestone-filled pozzolanic cement. Cement and Concrete Research 2000 30(11): 1827-1834. https://doi.org/10.1016/S0008-8846(00)00402-6

[20] Singh S, Nagar R, Agrawal V. Performance of granite cutting waste concrete under adverse exposure conditions. Journal of Cleaner Production 2016; 127: 172-182. https://doi.org/10.1016/j.jclepro.2016.04.034

[21] Chen J, Li BH, Ng PL, et al. Adding granite polishing waste to reduce sand and cement contents and improve performance of mortar[J]. Journal of Cleaner Production 2021; 279: 123653. https://doi.org/10.1016/j.jclepro.2020.123653

[22] Bakhoum ES, Garas GLK, Allam ME, et al. The role of nanotechnology in sustainable construction: a case study of using nano granite waste particles in cement mortar. Engineering Journal 2017; 21(4): 217-227.

https://doi.org/10.4186/ej.2017.21.4.217 
[23] Zhang HR, Ji T, He B, et al. Performance of ultrahigh performance concrete (UHPC) with cement partially replaced by ground granite powder (GGP) under different curing conditions. Construction and Building Materials 2019; 213: 469-482. https://doi.org/10.1016/j.conbuildmat.2019.04.058

[24] Taji I, Ghorbani S, Brito J, et al. Application of statistical analysis to evaluate the corrosion resistance of steel rebars embedded in concrete with marble and granite waste dust. Journal of Cleaner Production 2019; 210: 837-846. https://doi.org/10.1016/j.jclepro.2018.11.091

[25] Vijayalakshmi M, Sekar ASS, Ganesh Prabhu G. Strength and durability properties of concrete made with granite industry waste. Construction and Building Materials 2013; 46: 1-7. https://doi.org/10.1016/j.conbuildmat.2013.04.018

[26] Gautam L, Jain JK, Kalla P, et al. Sustainable utilization of granite waste in the production of green construction products: a review. Materials Today: Proceedings 2021; 44(6): 4196-4203.

https://doi.org/10.1016/j.matpr.2020.10.532

[27] Savadkoohi MS, Reisi M. Environmental protection based sustainable development by utilization of granite waste in reactive powder concrete. Journal of Cleaner Production 2020; 266: 121973.

https://doi.org/10.1016/j.jclepro.2020.121973

[28] Sadek DM, El-Attar MM, Ali HA. Reusing of marble and granite powders in self-compacting concrete for sustainable development. Journal of Cleaner Production 2016; 121: 1932.

https://doi.org/10.1016/j.jclepro.2016.02.044

[29] Gayarre FL, González JS, Boadella IL, et al. Use of waste from granite gang saws to manufacture ultrahigh performance concrete reinforced with steel fibers. Applied Sciences 2021; 11(4): 1764. https://doi.org/10.3390/app11041764

[30] Karimipour A, Ghalehnovi M. Influence of steel fibres on the mechanical and physical performance of self-compacting concrete manufactured with waste materials and fillers. Construction and Building Materials 2021; 267: 121806. https://doi.org/10.1016/j.conbuildmat.2020.121806

[31] Mandrawalia AK, Gaur A. Compressive and sorptivity characteristic of concrete modified with wollastonite fibre and waste granite fines. Materials Today: Proceedings 2021; 42(2): 1012-1016.

https://doi.org/10.1016/j.matpr.2020.12.005

[32] Jain A, Gupta R, Chaudhary S. Sustainable development of self-compacting concrete by using granite waste and fly ash. Construction and Building Materials 2020; 262: 120516. https://doi.org/10.1016/j.conbuildmat.2020.120516

[33] Singh S, Nande N, Bansal $P$, et al. Experimental investigation of sustainable concrete made with granite industry by-product. Journal of Materials in Civil Engineering 2017; 29(6): 04017017.

https://doi.org/10.1061/(ASCE)MT.1943-5533.0001862

[34] Patil MV, Patil YD. Effect of copper slag and granite dust as sand replacement on the properties of concrete. Materials Today: Proceedings 2021; 43(2): 1666-1677. https://doi.org/10.1016/j.matpr.2020.10.029

[35] Sern LJ, Cheah CB, Ramli MB. The setting behavior, mechanical properties and drying shrinkage of ternary blended concrete containing granite quarry dust and processed steel slag aggregate. Construction and Building Materials 2019; 215: 447-461.

https://doi.org/10.1016/j.conbuildmat.2019.04.162

[36] Zafar MS, Javed U, Khushnood RA, et al. Sustainable incorporation of waste granite dust as partial replacement of sand in autoclave aerated concrete. Construction and Building Materials 2020; 250: 118878.

https://doi.org/10.1016/j.conbuildmat.2020.118878
[37] Arivumangai A, Narayanan RM, Felixkala T. Study on sulfate resistance behaviour of granite sand as fine aggregate in concrete through material testing and XRD analysis. Materials Today: Proceedings 2021; 43(2): 1724-1729. https://doi.org/10.1016/j.matpr.2020.10.354

[38] Ghorbani S, Ghorbani S, Elmi A, et al. Simultaneous effect of granite waste dust as partial replacement of cement and magnetized water on the properties of concrete exposed to $\mathrm{NaCl}$ and $\mathrm{H} 2 \mathrm{SO} 4$ solutions. Construction and Building Materials 2021; 288: 123064. https://doi.org/10.1016/j.conbuildmat.2021.123064

[39] Jain KL, Sancheti G, Gupta LK. Durability performance of waste granite and glass powder added concrete. Construction and Building Materials 2020; 252: 119075. https://doi.org/10.1016/j.conbuildmat.2020.119075

[40] Tchadjié LN, Djobo JNY, Ranjbar N, et al. Potential of using granite waste as raw material for geopolymer synthesis. Ceramics International 2016; 42(2): 3046-3055. https://doi.org/10.1016/j.ceramint.2015.10.091

[41] Nadeem M, llyas S, Haq EU, et al. Improved water retention and positive behavior of silica based geopolymer utilizing granite powder. Silicon 2021; DOI: 10.1007/s12633-02101047-x.

https://doi.org/10.1007/s12633-021-01047-x

[42] Eroshkina $N$, Korovkin $M$. The effect of the mixture composition and curing conditions on the properties of the geopolymer binder based on dust crushing of the granite. Procedia Engineering 2016; 150: 1605-1609. https://doi.org/10.1016/j.proeng.2016.07.137

[43] Peng $\mathrm{H}$, Cui $\mathrm{C}$, Cai CS, et al. Microstructure and microhardness property of the interface between a metakaolin/GGBFS-based geopolymer paste and granite aggregate. Construction and Building Materials 2019; 221: 263-273.

https://doi.org/10.1016/j.conbuildmat.2019.06.090

[44] Alvi MAA, Khalifeh M, Agonafir MB. Effect of nanoparticles on properties of geopolymers designed for well cementing applications. Journal of Petroleum Science and Engineering 2020; 191: 107128.

https://doi.org/10.1016/j.petrol.2020.107128

[45] Zhao GQ, Wang QH, Huang XX. Experimental study on granite waste to produce concrete hollow blocks. New Building Materials 2018; 45(6): 116-118. (in Chinese)

[46] Hojamberdiev M, Eminov A, Xu Y. Utilization of muscovite granite waste in the manufacture of ceramic tiles. Ceramics International 2011; 37(3): 871-876. https://doi.org/10.1016/j.ceramint.2010.10.032

[47] Araújo AJM, Sousa ARO, Macedo DA, et al. Effects of granite waste addition on the technological properties of industrial silicate based-ceramics. Materials Research Express 2020; 6(12): 125205.

https://doi.org/10.1088/2053-1591/ab62e8

[48] Ngayakamo BH, Bello A, Onwualu AP. Development of ecofriendly fired clay bricks incorporated with granite and eggshell wastes. Environmental Challenges 2020; 1: 100006. https://doi.org/10.1016/j.envc.2020.100006

[49] Mathavan JJ, Patnaik A. Analysis of wear properties of granite dust filled polymer composite for wind turbine blade. Results in Materials 2020; 5: 100073.

https://doi.org/10.1016/j.rinma.2020.100073

[50] Awad AH, El-Gamasy R, El-Wahab AA, et al. Assessment of mechanical properties of HDPE composite with addition of marble and granite dust. Ain Shams Engineering Journal 2020; 11(4): 1211-1217. https://doi.org/10.1016/j.asej.2020.02.001

[51] Subhash C, Krishna MR, Raj MS, et al. Development of granite powder reinforced epoxy composites. Materials Today: Proceedings 2018; 5(5): 13010-13014.

https://doi.org/10.1016/j.matpr.2018.02.286 
[52] Karimi D, Crawford B, Milani AS. Manufacturing process and mechanical properties of a novel acrylonitrile butadiene styrene-based composite, with recycled natural granite micro-particles. Manufacturing Letters 2020; 23: 79-84. https://doi.org/10.1016/j.mfglet.2020.01.004

[53] Karbous MM, El-Wahab AA, El-Gamasy R, et al. Assessment of the mechanical properties of marble and granite dust-high impact polystyrene composites. Advances in Applied Sciences 2020; 5(3): 88-96.

https://doi.org/10.11648/j.aas.20200503.16

[54] Reddy BM, Reddy RM, Reddy BCM, et al. The effect of granite powder on mechanical, structural and water absorption characteristics of alkali treated cordia dichotoma fiber reinforced polyester composite. Polymer Testing 2020; 91: 106782.

https://doi.org/10.1016/j.polymertesting.2020.106782

[55] Awad AH, Abdel-Ghany AW, El-Wahab AA, et al. The influence of adding marble and granite dust on the mechanical and physical properties of PP composites. Journal of Thermal Analysis and Calorimetry 2020; 140(6): 2615-2623.

https://doi.org/10.1007/s10973-019-09030-w

[56] Pazniak A, Barantseva S, Kuzmenkova O, et al. Effect of granitic rock wastes and basalt on microstructure and properties of porcelain stoneware. Materials Letters 2018; 225: $122-125$.

https://doi.org/10.1016/j.matlet.2018.05.011

[57] Vieira CMF, Soares TM, Sánchez R, et al. Incorporation of granite waste in red ceramics. Materials Science and Engineering: A 2004; 373(1-2): 115-121. https://doi.org/10.1016/j.msea.2003.12.038

[58] Naga SM, Bondioli F, Wahsh MMS, et al. Utilization of granodiorite in the production of porcelain stoneware tiles. Ceramics International 2012; 38(8): 6267-6272. https://doi.org/10.1016/j.ceramint.2012.04.081

[59] Sadek HEH, Hessien MA, El-Shakour ZA, et al. The effect of sintering on the properties of magnesia-granite sludge ceramics shaped by temperature-induced forming. Journal of Materials Research and Technology 2021; 11: 264-273. https://doi.org/10.1016/j.jmrt.2021.01.016

[60] Lu JS, Li YD, Zou CM, et al. Effect of sintering additives on the densification, crystallization and flexural strength of sintered glass-ceramics from waste granite powder. Materials Chemistry and Physics 2018; 216: 1-7.

https://doi.org/10.1016/j.matchemphys.2018.02.053

[61] Lu JS, Li YD, Zou CM, et al. Effect of heating rate on the sinterability, crystallization, and mechanical properties of sintered glass-ceramics from granite waste. Journal of Thermal Analysis and Calorimetry 2019; 135(4): 1977-1985. https://doi.org/10.1007/s10973-018-7346-0

[62] Zou CM. Preparation and mechanical property of high strength and toughness glass-ceramics sintered from granite waste. Master dissertation, Nanchang Hangkong University, Nanchang, 2018.

[63] Zhang ZP. Preparation and Physical properties of glazed glass-ceramics sintered from granite waste. Master dissertation, Nanchang Hangkong University, Nanchang, 2020.

[64] Xue JW, Zhong JW, Mao YR, et al. Effect of CuO on crystallisation and properties of red $\mathrm{R} 2 \mathrm{O}-\mathrm{CaO}-\mathrm{MgO}-\mathrm{Al} 2 \mathrm{O} 3-$ $\mathrm{SiO} 2$ glass-ceramics from granite wastes. Ceramics International 2020; 46(14): 23186-23193.

https://doi.org/10.1016/j.ceramint.2020.06.099

[65] Gougazeh M, Bamousa A, Hasan A. Evaluation of granitic rocks as feldspar source: Al Madinah, western part of Saudi Arabia. Journal of Taibah University for Science 2018; 12(1): 21-36.

https://doi.org/10.1080/16583655.2018.1451111
[66] Silva AC, Carolina SD, Sousa DN, et al. Feldspar production from dimension stone tailings for application in the ceramic industry. Journal of Materials Research and Technology 2019; 8(1): 1-7.

https://doi.org/10.1016/j.jmrt.2018.02.011

[67] El-Omla M, Shata S. Recovery of feldspar raw material from granite rocks for ceramic and porcelain industries. Geology and Resources 2008; 17(3): 235-240.

[68] Saklar S, Oktay C, Karadeniz M. Beneficiation of feldspar from Yozgat region granites. Key Engineering Materials 2004; 264-268: 1419-1422.

https://doi.org/10.4028/www.scientific.net/KEM.264-268.1419

[69] Demir C. Selective separation of Na-and K-feldspar from weathered granites by flotation in HF medium. CeramicsSilikáty 2010; 54(1): 60-64.

[70] Vrbický T, Přikryl R. Recovery of some critical raw materials from processing waste of feldspar ore related to hydrothermally altered granite: laboratory-scale beneficiation. Minerals 2021; 11(5): 455.

https://doi.org/10.3390/min11050455

[71] Li QQ, Li AW, Yu XL. Soil acidification of the soil profile across Chengdu Plain of China from the 1980s to 2010s. Science of the Total Environment 2020; 698: 134320. https://doi.org/10.1016/j.scitotenv.2019.134320

[72] Yang LY, Wei TC, Li SW, et al. Immobilization persistence of $\mathrm{Cu}, \mathrm{Cr}, \mathrm{Pb}, \mathrm{Zn}$ ions by the addition of steel slag in acidic contaminated mine soil. Journal of Hazardous Materials 2021; 412: 125176.

https://doi.org/10.1016/j.jhazmat.2021.125176

[73] Silva MTB, Hermo BS, Garcia-Rodeja E, et al. Reutilization of granite powder as an amendment and fertilizer for acid soils. Chemosphere 2005; 61(7): 993-1002.

https://doi.org/10.1016/j.chemosphere.2005.03.010

[74] Ciceri D, Oliveira M, Allanore A. Potassium fertilizer via hydrothermal alteration of K-feldspar ore. Green Chemistry 2017; 19: 5187-5202.

https://doi.org/10.1039/C7GC02633A

[75] Zhao QF, Li XY, Wu QS, et al. Evolution of mineral phases and microstructure of high efficiency Si-Ca-K-Mg fertilizer prepared by water-insoluble K-feldspar. Journal of Sol-Gel Science and Technology 2020; 94: 3-10. https://doi.org/10.1007/s10971-020-05284-1

[76] Reehana S, Kumar KS. Effect of granite dust in improving engineering properties of black cotton soil, International Journal of Scientific Engineering and Technology Research 2018; 7(9): 1735-1739.

[77] Suliman MO, Alkherret AJ. Using fine silica sand and granite powder waste to control free swelling behavior of high expansive soil. Modern Applied Science 2021; 15(1): 53-62. https://doi.org/10.5539/mas.v15n1p53

[78] Ahmed NAS, Abdel-Latif ML, Sanad SA, et al. Utilization of industrial granitic waste as adsorbent for phosphate ions from wastewater. International Journal of Scientific \& Engineering Research 2020; 11(10): 184-194.

[79] Ferreira SAD, Donadia JF, Gonçalves GR, et al. Photocatalytic performance of granite waste in the decolorization and degradation of Reactive Orange 122. Journal of Environmental Chemical Engineering 2019; 7(3): 103144

https://doi.org/10.1016/j.jece.2019.103144

[80] Barral MT, Paradelo R, Liste A, et al. Reutilization of granite powder as a component of permeable reactive barriers for the treatment of $\mathrm{Cr}(\mathrm{VI})$-contaminated waters. Spanish Journal of Soil Science 2014; 4(2): 179-191.

[81] Lasheen MR, Ashmawy AM, Ibrahim HS, et al. Immobilization technologies for the management of hazardous industrial waste using granite waste (case study). Korean Journal of Chemical Engineering 2016; 33(3): 914921.

https://doi.org/10.1007/s11814-015-0187-7 
[82] Aydin G, Kaya S, Karakurt I. Utilization of solid-cutting waste of granite as an alternative abrasive in abrasive waterjet cutting of marble. Journal of Cleaner Production 2017; 159: 241-247.

https://doi.org/10.1016/j.jclepro.2017.04.173

[83] Sarici DE, Ozdemir E. Utilization of granite waste as alternative abrasive material in marble grinding processes.
Journal of Cleaner Production 2018; 201: 516-525. https://doi.org/10.1016/j.jclepro.2018.08.050

[84] Gomes VR, Babisk MP, Vieira CMF, et al. Ornamental stone wastes as an alternate raw material for soda-lime glass manufacturing. Materials Letters 2020; 269: 127579. https://doi.org/10.1016/j.matlet.2020.127579

Received on 22-06-2021

DOI: https://doi.org/10.31875/2410-4701.2021.08.5

(c) 2021 Wang et al.; Zeal Press.

This is an open access article licensed under the terms of the Creative Commons Attribution Non-Commercial License (http://creativecommons.org/licenses/by-nc/3.0/) which permits unrestricted, non-commercial use, distribution and reproduction in any medium, provided the work is properly cited. 